\title{
Review \\ Hydrolyzed Proteins and Vegetable Peptides: Anti-Inflammatory Mechanisms in Obesity and Potential Therapeutic Targets
}

\author{
Amanda Fernandes de Medeiros ${ }^{1}$, Jaluza Luana Carvalho de Queiroz ${ }^{1}$, Bruna Leal Lima Maciel ${ }^{2,3}$ \\ and Ana Heloneida de Araújo Morais 1,2,3,* \\ 1 Postgraduate Biochemistry and Biology Molecular Program, Biosciences Center, Federal University of Rio \\ Grande do Norte, Natal 59078-970, RN, Brazil; amanda-nut@hotmail.com (A.F.d.M.); \\ luh_nutri@hotmail.com (J.L.C.d.Q.) \\ 2 Department of Nutrition, Center for Health Sciences, Federal University of Rio Grande do Norte, \\ Natal 59078-970, RN, Brazil; brunalimamaciel@gmail.com \\ 3 Postgraduate Nutrition Program, Center for Health Sciences, Federal University of Rio Grande do Norte, \\ Natal 59078-970, RN, Brazil \\ * Correspondence: ana.morais@ufrn.br; Tel.: +55-84-9910-61887
}

\section{check for}

updates

Citation: de Medeiros, A.F.; de Queiroz, J.L.C.; Maciel, B.L.L.; de Araújo Morais, A.H. Hydrolyzed Proteins and Vegetable Peptides: Anti-Inflammatory Mechanisms in Obesity and Potential Therapeutic Targets. Nutrients 2022, 14, 690. https://doi.org/10.3390/ nu14030690

Academic Editors: Sara Baldassano and Sumei Liu

Received: 12 January 2022

Accepted: 4 February 2022

Published: 6 February 2022

Publisher's Note: MDPI stays neutral with regard to jurisdictional claims in published maps and institutional affiliations.

Copyright: (c) 2022 by the authors. Licensee MDPI, Basel, Switzerland. This article is an open access article distributed under the terms and conditions of the Creative Commons Attribution (CC BY) license (https:/ / creativecommons.org/licenses/by/ $4.0 /)$.

\begin{abstract}
Chronic low-grade inflammation is present in overweight and obesity, causing changes in several metabolic pathways. It impairs systemic functioning and positively feeds back the accumulation of more adipose tissue. Studies with hydrolyzed proteins and plant peptides have demonstrated a potential anti-inflammatory and immunomodulatory effect of these peptides. However, it is challenging and necessary to explore the mechanism of action of such molecules because understanding their effects depends on their structural characterizations. Furthermore, the structure might also give insights into safety, efficacy and efficiency, with a view of a possible health application. Thus, the present narrative review aimed to discuss the mechanisms of action of hydrolyzed proteins and plant peptides as anti-inflammatory agents in obesity. Keywords and related terms were inserted into databases for the search. Based on the studies evaluated, these biomolecules act by different pathways, favoring the reduction of inflammatory cytokines and adipokines and the polarization of macrophages to the M2 phenotype. Finally, as a future perspective, bioinformatics is suggested as a tool to help understand and better use these molecules considering their applicability in pre-clinical and clinical studies.
\end{abstract}

Keywords: amino acids; peptides and proteins; anti-inflammatory agents; anti-obesity agents; inflammation mediators

\section{Introduction}

Obesity and overweight represent a serious global public health problem, and obesity is considered a pandemic [1], with considerable economic impacts [2]. According to the World Health Organization (WHO) data, in adults, obesity has almost tripled since 1975 and more than quadrupled in children and adolescents $[3,4]$.

Overweight and obesity are, as defined by the WHO, "abnormal or excessive accumulation of fat that can harm health" [3]. The excess of adipose tissue, especially the visceral, progressively favors the emergence of insulin resistance, inflammation, lipotoxicity, mitochondrial dysfunction and alteration in protein synthesis, and these disorders can result in diseases such as type 2 diabetes mellitus (T2DM), dyslipidemias, cardiovascular diseases (CVDs), hepatic steatosis and autoimmune diseases [5-8].

In overweight, there is a low-grade systemic chronic inflammatory response, which favors the establishment of obesity, generating a "vicious cycle" that positively feeds back the accumulation of more adipose tissue and activates immune cells, releasing cytokine and adipokines $[6,8-11]$. 
The first line of action for the treatment of obesity is changing habits for a healthy diet and physical activity practice. However, individuals commonly present difficulty and/or low access to primary treatment. According to the need of each case, it is necessary to use medications, which have adverse effects and side effects. Thus, studying potential molecules, such as plant peptides, can be a strategy for treatment with adjuvants [12,13].

Several studies explore the action of anti-inflammatory agents [13-16], such as proteins of vegetable origin [14,15] and bioactive peptides [17].

Bioactive peptides and hydrolyzed proteins, different from integrative proteins, commonly present low molecular weight structures, favoring digestibility and bioavailability [18]. In addition, peptides have several physical-chemical properties that involve solubility, the possibility of emulsification, affinity with lipids and foaming, depending on the amino acid constitution, structure and size. This versatility attracts the pharmaceutical and food industry to develop foods with added functional value [19].

Thus, increasingly, the industry has invested significantly in research in this area. However, standardization of the process of purification and characterization of bioactive peptides is necessary in regard to the following steps: (1) extraction, fractionation and direct protein isolation from the source; (2) the characterization of the proteins of interest; (3) hydrolysis, which, at the end of the digestion process, will result in a pool of peptides; (4) purification, characterization and sequencing of each peptide released from hydrolysis;

(5) bioactivity tests of peptides, registering all relevant data in the bioinformatics database,

(6) most promising peptides can be synthesized for in vitro, pre-clinical and clinical trials. All the processes and also the synthesis have a high cost [19-21].

Due to the lengthy process and high cost for purification and characterization, it is of paramount importance to compile data of hydrolyzed proteins and peptides from plant sources to understand the mechanism of action of these molecules in the search for candidates with potential anti-inflammatory and immunomodulatory effects.

Although proteins of plant origin are widely studied, the universe of the effects of bioactive peptides derived from vegetables is still unknown, and it is necessary to explore them also considering mechanistic aspects. Therefore, based on the importance of this discussion and the hypothesis of the applicability of these peptides in the prevention and/or therapy of inflammation present in overweight and obesity, this article aims to conduct a review narratively and systematically organized concerning the mechanisms of action of hydrolyzed proteins and peptides of plant source in inflammation affected by adipose tissue excess. For the inclusion of articles, searches were performed in databases using descriptors and terms that include obesity, inflammation, proteins and peptides of plant origin.

\section{Hydrolyzed Proteins, Peptide Pool and Their Respective Anti-Inflammatory Mechanisms of Action}

The hydrolysis process on proteins can generate different peptides depending on the enzyme used in the reaction, the enzymatic combination and the reaction time. All these factors alter the developed products, which should be well evaluated. Furthermore, there is no way to define which peptide specifically had a particular effect in a peptide pool or even if the action was due to the set of peptides contained in the hydrolysis pool [22]. Considering these observations, the mechanisms of the pool of hydrolyzed proteins from some plant sources stand out.

Soy (Glycine max) is a legume source of proteins, with high nutritional value, economically crucial in the world market and widely studied [23,24]. Martinez-Villaluenga et al. [25] observed that soy-derived peptides, from hydrolysis with Alcalase (SPH), acted by reducing lipid accumulation in 3T3-L adipocytes culture because it reduced the expression of lipoprotein lipase $(L P L)$ and fatty acid synthase (FAS) genes. In addition, it decreased, in a mouse macrophage cell culture (RAW264.7) stimulated with lipopolysaccharide (LPS), the production of NO, prostaglandin-endoperoxide synthase 2 (PGE2), the protein expression of nitric oxide synthase (iNOS) and cyclooxygenase-2 (COX-2). 
Yi et al. [24] investigated the effect of soy protein-derived peptides (SBP)—acquired commercially-on inflammation in raw 264.7 cell culture. SBP reduced the concentrations and mRNA expression of the cytokines TNF- $\alpha$, IL- $1 \beta$ and IL- 6 , and the protein expression of TNF- $\alpha$ occurred dose-dependently. In addition, BPS minimized the expression of both lymphocytic antigen 96 mRNA (LY96) and the toll 4 receptor protein (TRL4) dosedependently, suppressing the phosphorylation of the $\alpha-\mathrm{NF}-\kappa \mathrm{B}$ inhibitor $(\mathrm{I} \kappa \mathrm{B} \alpha)$, suggesting a reduction in NF- $\kappa$ B activation. The phosphorylation of NF- $\kappa$ B, P-85, P-AKT and P-IKKe was evaluated, and the higher doses of SPB reduced the expression of such proteins [24].

Oseguera-Toledo et al. [26] analyzed the in vitro antioxidant capacity of the common bean protein (Phaseolus vulgaris L.) of two varieties, Negro 8025 (N) and Pinto Durango, (P) and its action in raw macrophage culture 264.7. Both varieties showed increased antioxidant capacity as the hydrolysis time with Alcalase occurred (with digestion product ranging between 43 and $50 \mathrm{kDa}$ and between 20 and $25 \mathrm{kDa}$ ), favoring the reduction of oxidative stress. Therefore, the peptide pool was evaluated on macrophage culture compared with the induction of inflammation by LPS. Macrophages treated with common bean hydrolysate induced a lower production of $\mathrm{NO}$ and iNOS. In addition, a potent reduction in PGE2 production and an intense reduction in COX-2 protein expression after 120 and 180 min of enzymatic hydrolysis was observed. The pool of hydrolyzed peptides significantly reduced both the activation of the nuclear kappa B factor $(\mathrm{NF}-\kappa \mathrm{B})$ and the nuclear translocation of subunits p65 and p50 [26].

The authors then tried to characterize these peptides, performing theoretical enzymatic digestion (by the Expert Protein Analysis System-ExPaSy) with the enzymes used in the experiment. The peptides found presented molecular masses, similar to those found by electrophoresis in polyacrylamide gel with sodium-dodecylsulfate polyacrylamide gel electrophoresis (SDS-PAGE). According to theoretical digestion, the peptides RSGSAILVLV, SFATSLREE, DNPIFSDHQ, SGSYFVDGHH and NEGEAH were candidates for synthesis in after-studies, especially those containing residues of asparagine (Asn) [26].

Another vegetable protein of the legume family, extracted from lupine (Lupinus angustifolius L.), was hydrolyzed (LPHs) with Izyme AL and/or Alcalase 2.4 L and evaluated in vitro for its inhibitory potential of enzymes involved in the inflammatory process [27]. The Izyme enzyme has trypsin-like activity, and Alcalase is a non-specific endoprotease. LPHs hydrolyzed with Izyme AL for 60 min inhibited phospholipase $A_{2}\left(P_{2} A_{2}\right)$ [27]. PLA 2 is an enzyme that catalyzes the hydrolysis of phospholipids, releasing phosphatidylcholine and phosphatidylcholine, which promotes synthesis of arachidonate-the precursor for the synthesis of eicosanoids: prostaglandin, leukotriene and thromboxane. Therefore, the mechanism of LPHs in inhibiting PLA 2 is directly related to the reduction of lipid peroxidation. This metabolic pathway is the target of several steroidal anti-inflammatory drugs, such as prednisone and prednisolone [28].

Further, all the hydrolyzed LPHs tested inhibited COX-2 by 60\% [27] without the distinction of hydrolysis reaction time. Regarding thrombin inhibition, this did not exceed 40\%, and inhibition of the enzyme transglutaminase (TG) occurred when there was combined hydrolysis of Izyme AL and Alcalase. The authors reported a difference between the peptides generated according to the time and enzyme used, which may have diverse potentials under the inhibition of the enzymes involved in the inflammatory cascade tested [27].

In another study with digested LPHs also using Izyme AL and Alcalase 2.4, evaluating their effects on monocyte cell culture (THP-1, ATCC ${ }^{\circledR}$ no. TIB-202 ${ }^{\mathrm{TM}}$ ), there was a reduction in the expression of mRNA of inflammatory cytokines, TNF, IL- 6 and $I L-\beta$, markers of the M1-like phenotype of macrophages. Although there was no difference in the expression of mRNA of the $I L-10$, there was an increase in the expression of the anti-inflammatory marker gene of chemokine (C-C motif) ligand 18 (CCL18), which is a marker of the phenotype M2. NO production halved and CC chemokine receptor type 2 (CCR2) mRNA expression and the THP-1 macrophage migration index statistically decreased, although digested LPHs did not decrease monocyte chemoattractant protein-1 (MCP-1, monocyte chemoattractant protein-1). Thus, according to the authors, the pool of peptides derived from lupine- 
derived protein hydrolysis favored macrophage polarization for type M2, which has an anti-inflammatory character [29].

More recently, LPHs hydrolyzed only with Alcalase 2.4. were evaluated in an ex vivo model in human peripheral blood mononuclear cells (PBMCs) of healthy donors. Cruz-Chamorro et al. [30] reported the activity of LPHs in PBMCs as immunomodulators and antioxidants via superoxide dismutase (SOD) and catalase (CAT) enzyme activities. First, no effects of LPHs on cell viability were detected. Therefore, the immunological effect of this peptide pool was evaluated, and the tested doses $(0.5$ and $0.75 \mathrm{mg} / \mathrm{mL})$ significantly reduced the concentrations of pro-inflammatory Th1 cytokines: IL-2, IL-12, IFN- $\gamma$ and TNF, and decreased the concentrations of IL-17, IL-9 and IL-13. However, there was a reduction in the production of IL-10, which is an anti-inflammatory cytokine. LPHs were able to increase the expression of mRNA and the enzymatic activity of SOD and CAT, not altering the mRNA expression of glutathione peroxidase (GPx) and glutathione reductase (GR) [30]. SOD and CAT are essential antioxidant enzymes in the redox potential, balancing oxidative stress (OE), chronically unbalanced in the context of obesity, causing a vicious cycle between mitochondrial dysfunction and increased production of reactive oxygen species (ROS). Moreover, the increase in OE has a strong relationship with visceral fat accumulation and metabolic syndrome (MS) [31,32].

In the study by Cruz-Chamorro et al. [30], LPHs also presented a polarizing character for the Th2 protective phenotype, considering a system based on unimmortalized human cells, and increased the total antioxidant capacity (TAC). In addition, the need to characterize each peptide generated from hydrolysis was also discussed in the study.

With the same objective of evaluating the immunomodulatory effect and antioxidant capacity of hydrolyzed wheat gluten protein (WGPH) with Alcalase 2.4 L, Cruz-Chamorro et al. [33] tested WGPHs in PBMCs of healthy donors. Even though wheat is one of the main food sources for the world population, it is also a problem for many individuals with celiac disease, which also has a strong inflammatory aspect $[33,34]$. Thus, the study suggests that the hydrolysis process can help reduce wheat antigenicity [33].

In the ex vivo model, WGPHs decreased the production of IFN- $\gamma$, IL-17 as well as reduced the expression of mRNA of $i N O S$ and the production of NO. However, it also minimized the production of IL-10 and did not affect IL-4 and significantly increased the expression of $I L-10$ mRNA. Among the antioxidant enzymes, CAT, GPx, SOD and GR, only the expression of GR mRNA was significantly increased, as well as increased antioxidant parameters: TAC, oxygen radical absorbance capacity (ORAC), ferric reducing antioxidant power (FRAP) and equivalent antioxidant capacity of trolox (TEAC) and antioxidant capacity equivalent to trolox (TEAC). Finally, the authors discuss that WGPHs significantly increased the molar ratios of Th2/Th1 and Th2/Th17 cytokines, promoting a shift in the pro-inflammatory response towards an anti-inflammatory microenvironment [33].

According to the studies addressed, the pool of peptides derived from direct protein hydrolysis from the source or even acquired commercially presented promising results as anti-inflammatory agents. Most of them acted by reducing inflammatory cytokines, favoring the polarization of M2 macrophages and showing a significant antioxidant response (Table 1). 
Table 1. Anti-inflammatory and immunomodulatory effects of hydrolyzed vegetable proteins reported in the literature.

\begin{tabular}{|c|c|c|c|}
\hline Vegetable Protein & Cell Culture/Enzyme Assay & Enzymes Used in Hydrolysis & Outcomes \\
\hline $\begin{array}{l}\text { Hydrolyzed soy protein } \\
\text { (SPH) [25] }\end{array}$ & Macrophage cells, RAW 264.7 & Alcalase $2.4 \mathrm{~L}$ & $\begin{array}{c}\downarrow \text { Expression of LPL and FAS genes } \\
\downarrow \text { Production of NO and iNOS } \\
\downarrow \text { Production of PGE2 and COX-2 }\end{array}$ \\
\hline $\begin{array}{c}\text { Common beans } \\
\text { (Phaseolus vulgaris L.), } \\
\text { varieties Negro } 8025(\mathrm{~N}) \\
\text { and Pinto Durango } \\
\text { (P) [26] }\end{array}$ & Macrophage cells, RAW 264.7 & Alcalase $2.4 \mathrm{~L}$ & $\begin{array}{c}\downarrow \text { NO production } \\
\downarrow \text { Production PGE } 2 \text { and COX-2 } \\
\downarrow \text { Nuclear translocation of NF- } \mathrm{kB} \text { subunits, } \\
\text { p50 and p65 } \\
\downarrow \text { NF- } \kappa \text { B activation }\end{array}$ \\
\hline $\begin{array}{c}\text { Seeds of lupine } \\
\text { (Lupinus angustifolius L.) } \\
\text { (LPH) [27] }\end{array}$ & In vitro inhibition of enzymes & Izyme AL and Alcalase $2.4 \mathrm{~L}$ & $\begin{array}{c}\downarrow \mathrm{PLA}_{2} \text { and thrombin activity when LPH } \\
\text { hydrolyzed with Izyme } \\
\downarrow \text { Transglutaminase activity when LPH } \\
\text { hydrolyzed with Izyme and Alcalase } \\
\otimes \text { COX-2 activity by LPH without } \\
\text { distinction of time or type of hydrolysis }\end{array}$ \\
\hline $\begin{array}{c}\text { Seeds of lupine } \\
\text { (Lupinus angustifolius L.) } \\
\text { (LPH) [29] }\end{array}$ & $\begin{array}{l}\text { THP-1 monocytes (human acute } \\
\text { monocytic leukemia) } \\
\left(\text { ATCC }^{\circledR}-\text { TIB-}^{2} 202^{\mathrm{TM}}\right)\end{array}$ & Izyme AL and Alcalase $2.4 \mathrm{~L}$ & $\begin{array}{c}\uparrow \text { CCL18 expression } \\
\downarrow \text { Expression of TNF, IL-6 and IL-1 } \beta \\
\downarrow \text { NO production } \\
\downarrow \text { CCR2 expression }\end{array}$ \\
\hline $\begin{array}{c}\text { Seeds of lupine } \\
\text { (Lupinus angustifolius L.) } \\
\text { (LPH) [30] }\end{array}$ & $\begin{array}{l}\text { PBMCs of } 53 \text { healthy } \\
\text { adult donors }\end{array}$ & Alcalase $2.4 \mathrm{~L}$ & $\begin{array}{c}\downarrow \text { Expression of IL-2, IL-12, IFN- } \gamma, \text { TNF, } \\
\text { IL-17, IL-9 and IL-13 } \\
\uparrow \text { Gene expression and SOD and } \\
\text { CAT activity } \\
\uparrow \text { TAC } \\
\uparrow \text { Protection against cell death mediated by } \\
\text { oxidative stress induced by } \mathrm{H}_{2} \mathrm{O}_{2}\end{array}$ \\
\hline $\begin{array}{l}\text { Wheat gluten protein } \\
\text { (WGPHs) [33] }\end{array}$ & $\begin{array}{l}\text { PBMCs of } 39 \text { healthy } \\
\text { adult donors }\end{array}$ & Alcalase $2.4 \mathrm{~L}$ & $\begin{array}{c}\downarrow \text { Production of IFN- } \gamma \text { and IL-17 } \\
\downarrow \text { iNOS gene expression and NO production } \\
\downarrow \text { Cell proliferation of Th1 and Th17 } \\
\uparrow \text { GR gene expression } \\
\uparrow \text { TAC, ORAC, FRAP e TEAC } \\
\uparrow \text { Th2/Th1 and Th2/Th17 Balance Sheet }\end{array}$ \\
\hline $\begin{array}{l}\text { Pool of soy-derived } \\
\text { peptides (Glycine max) } \\
\text { (SBP) [24] }\end{array}$ & Macrophage cells, RAW 264.7 & $\begin{array}{l}\text { The peptide pool was acquired } \\
\text { commercially }\end{array}$ & $\begin{array}{c}\downarrow \text { Gene expression and activity of TNF- } \alpha, \\
\text { IL- } 1 \beta \text { and IL-6 } \\
\downarrow \text { LY96 gene expression } \\
\downarrow \text { TLR4 expression } \\
\downarrow \text { Phosphorylation of IkB } \alpha \\
\downarrow \text { P-85, P-AKT and P-IKKe expression }\end{array}$ \\
\hline
\end{tabular}

$\downarrow$ Reduces, $\uparrow$ Increases, $\otimes$ Inhibits.

\section{Anti-Inflammatory Mechanisms of Action of Purified Peptides Obtained from Hydrolyzed Proteins of Plant Origin}

Bioactive peptides are oligopeptides usually inactive or latent within intact proteins, only released through enzymatic hydrolysis, fermentation or physiological digestion, thus becoming active to perform important functions according to their structure and composition [18].

Due to the various potential therapeutic effects of peptides-such as anticoagulant, chelating effect, anti-obesity, antioxidant, antimicrobial, anti-diabetic [19,20,35]—there is an interest in discovering their mechanism of action and safety. In the search for studies with peptides obtained from hydrolyzed proteins of plant source, those with experimental models in cell cultures to verify their anti-inflammatory activity were found.

According to Millán-Linares et al. [36], the peptide derived from the protein isolated from the lupine of the legume Lupinus angustifolius L., whose amino acid sequence is GPETAFLR, with molecular mass $<10 \mathrm{kDa}$, showed anti-inflammatory activity in a culture of THP- 1 cells derived from macrophages. Octapeptide was able to reduce the protein expression of TNF, IL-1 $\beta$, CCL2 and NO production, and further increased IL-10 cytokine.

More recently, Paz et al. [37] made progress in studies with the octapepetid GPETAFLR, analyzing it in a culture of monocytes derived from PBMCs of healthy donors. The effect was a reduction in classical monocytes $\left(\mathrm{CD} 14^{++} \mathrm{CD} 16^{-}\right)$, which represent the main fraction among the types of monocytes, reduction in CCR2 protein and mRNA expression, favoring the polarization for M1-like, and reduction in response to LPS, which secretes 
inflammatory cytokines [38]. Due to this characteristic, the authors also analyzed and verified that the peptide reduced the protein expression of CCR2, the secretion of TNF- $\alpha$, IL- $1 \beta$ and IL- 6 and the expression of the genes of these cytokines dose-dependently. In addition, GPETAFLR increased the secretion and gene expression of $I L-10$. Regarding the macrophage polarization assay, GPETAFLR reduced the mRNA expression of CD80 and CD64 and increased CD200R and C receptor of mannose type 1 (MRC-1) in M0; i.e., there was a decrease in the pro-inflammatory activity of the M1-like phenotype.

A soy tripeptide (Glicine max), whose sequence is FLV, was tested in macrophage and adipocytes culture by Kwak et al. [39]. It inhibited the secretion of TNF- $\alpha$, MCP-1 and IL-6, and the anti-inflammatory mechanism was explained by the inhibition of TNF- $\alpha$-induced activation of the C-Jun N-terminal kinase (JNK)/ kinase IKB (IKK) signaling pathway and negative regulation of IB in adipocytes. In addition, adipocytes culture expressed a peptide carrier protein 2 (PepT2). This protein was responsible for transporting the FLV peptide to the intracellular medium, acting by deregulating the inflammatory signaling induced by TNF- $\alpha$ and favoring insulin sensitivity.

In another study, by Hashidume et al. [40], soy-derived peptides had insulin-like action in skeletal muscle cells (rat L6 and mouse C2C12). The studied peptides were leginsulin 1_36 and 1_37; the difference between them is a GLY residue in the C-terminal. Both peptides activated protein kinase B (Akt) and increased the translocation of glucose transporter 4 (GLUT4), suggesting insulin-like activity. The residues I25, F28, V29, F31 and I33 on the peptide surface were crucial for affinity with the storage protein of soybean seed basic $7 \mathrm{~S}$ globulin protein $(\mathrm{Bg})$, which has a structure similar to the insulin receptor [41].

Peptides derived from sunflower seed (Helianthus annuus L.) also present bioactive properties [42]. Four small and non-polar peptides were obtained, sequenced (YFVP, SGRDP, MVWGP and TGSYTEGWS) and tested in THP-1 cells (ATCC ${ }^{\circledR}$ TIB-202 ${ }^{\mathrm{TM}}$ ). All were able to inhibit the activation of NF-KB by IL-1, and the last two peptides had an increased effect on this inhibition. In addition, the CD14 surface marker induction also increased. However, only MVWGP and TGSYTEGWS increased the protein expression of CD86. The peptide containing the Met residue presented the most promising anti-inflammatory and immunomodulatory effect among the four studied peptides of sunflower seed. According to the authors, the explanation is not completely clear [42]. However, the Met is a precursor of S-adenosil-L-methionine (SAMe or AdoMet), which is an enzyme with potential alkylating, a methyl donor, actively participating in numerous biochemical processes, such as a glutathione precursor (GSH), which acts in the detoxification process [43,44].

Among the three peptides obtained from corn protein (zein), the one with Met was also highlighted in the study by Liang et al. [45]. In this research, the three synthesized peptides (PPYLSP, IIGGAL and FLPPVTSMG) were tested for their anti-inflammatory capacity in endothelial cell culture (EA.hy926, CRL-2922 ${ }^{\mathrm{TM}}$ ) and monoblasts (U937, CRL-1593.2 ${ }^{\mathrm{TM}}$ ). All the peptides inhibited the protein expression of intercellular adhesion molecule-1 (ICAM-1) and vascular cell adhesion molecule- 1 (VCAM-1) induced by TNF- $\alpha$ and reduced the adhesion of monocytes to endothelial cells, with the peptide FLPPVTSMG presenting the best results. They also reduced the formation of superoxide, which is directly linked to oxidative stress, minimized the expression of TNF- $\alpha$ receptor 1 (TNFR-1)-related to inflammation and apoptosis-but not of receptor 2 TNF- $\alpha$ (TNFR-2), which has a primary function of cellular survival. The anti-inflammatory action of these peptides seemed to be independent of the degradation of $\operatorname{I\kappa } \mathrm{B} \alpha$ and IкB $\beta$ due to the low effect in the experiment. However, they inhibited the phosphorylation of p65, one of the dimers involved with the NF- $\mathrm{KB}$ pathway, thus inhibiting inflammatory signaling [45].

By analyzing the mechanism of action of plant peptides in inflammation, it is possible to infer that they act by reducing the release of inflammatory cytokines. This action favors a breakdown of positive feedback between fat accumulation and inflammatory cytokines, inhibiting NF- $\mathrm{kB}$ and reducing the expression of the TNF- $\alpha$ receptor (Table 2). 
Table 2. Anti-inflammatory and immunomodulatory effects of plant peptides reported in the literature.

\begin{tabular}{|c|c|c|c|}
\hline Vegetable Protein & Cell Culture & Peptide(s) & Outcomes \\
\hline $\begin{array}{l}\text { Seeds of lupine (Lupinus angustifolius L.) } \\
\text { (LPH) [36] }\end{array}$ & $\begin{array}{l}\text { Thp-1 monocytes (acute monocytic human } \\
\left.\text { leukemia) (ATCC }{ }^{\circledR}-\text { TIB-}^{202} 2^{\mathrm{TM}}\right) \text {. }\end{array}$ & GPETAFLR & 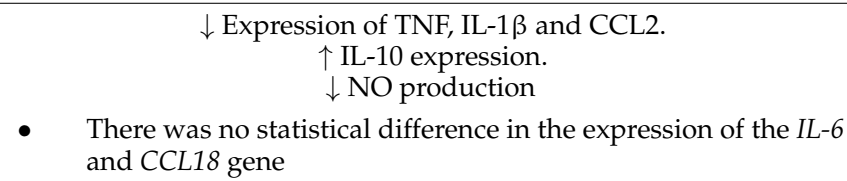 \\
\hline Soy (Glicine max) [39] & $\begin{array}{l}\text { Macrophage cells, RAW } 264.7 \text { and } \\
\text { adipocytes 3T3-L1 }\end{array}$ & FLV & $\begin{array}{l}\text { Release of TNF- } \alpha, \text { MCP-1, IL-1 } \beta \text { and IL- } 6 \\
\uparrow \text { Increasing IL-10 production and gene expression } \\
\otimes \text { Signaling molecules JNK and IKK } \\
\otimes \text { IkB } \alpha \text { degradation } \\
\uparrow \text { Insulin response and glucose uptake } \\
\text { - FlV can be transported to adipocytes by PepT2 and block TNF- } \\
\alpha \text {-induced inflammatory signaling. }\end{array}$ \\
\hline $\begin{array}{l}\text { Soja (Glycine max)-variant leginsulin } \\
\text { (Leg_1_37 and Leg_1_36) [40] }\end{array}$ & $\begin{array}{l}\text { Rat L6 and mouse C2C12 skeletal } \\
\text { muscle cells. }\end{array}$ & $\begin{array}{l}\text { ADCNGACSPFEVPPCRSRDCRCVPIGLFVGFCIHPTG } \\
\text { and } \\
\text { ADCNGACSPFEVPPCRSRDCRCVPIGLFVGFCIHPT }\end{array}$ & $\begin{array}{l}\quad \diamond \text { Akt } \\
\quad \uparrow \text { GLUT4 translocations to the plasma membrane. } \\
\text { - } \quad \text { Leg1_37 showed insulin-like activity } \\
\text { Amino acid residues I25, F28, V29, F31 and I33are critical for } \\
\text { affinity with Bg. }\end{array}$ \\
\hline $\begin{array}{l}\text { Seeds of lupine (Lupinus angustifolius L.) } \\
\text { [37] }\end{array}$ & PBMCs from healthy adult donors & GPETAFLR & $\begin{array}{c}\left.\downarrow \text { Population of classical monocytes (CD14 }{ }^{++} \text {CD16 }{ }^{-}\right) . \\
\downarrow \text { Expression of CCR2 and CCL2. } \\
\uparrow \text { Production and expression of IL-10 genes. } \\
\downarrow \text { Gene expression and production of IL-1 } 1 \beta \text {, IL-6 and TNF- } \alpha \text {. } \\
\downarrow \text { Pro-inflammatory activity of the M1-like phenotype. }\end{array}$ \\
\hline Sunflower seed (Helianthus annuus L.) [42] & $\begin{array}{c}\text { Thp-1 monocytes (acute monocytic human } \\
\text { leukemia) (ATCC }{ }^{\circledR}-\text { TIB-}^{202^{\mathrm{TM}}} \text { ) }\end{array}$ & $\begin{array}{l}\text { YFVP, } \\
\text { SGRDP, } \\
\text { MVWGP and } \\
\text { TGSYTEGWS }\end{array}$ & $\begin{array}{l}\text { - } \quad \text { Small, non-polar peptides } \\
\qquad \text { NF- }-\mathrm{B} \text { activated by IL-1 } \beta \\
\downarrow \text { Expression of CD14 and CD86 } \\
\text { - } \quad \text { Peptides with Met had superior immunomodulatory effect }\end{array}$ \\
\hline Corn (Zein) [45] & $\begin{array}{l}\left.\text { Endothelial cells, EA.hy926 (CRL-2922 }{ }^{\mathrm{TM}}\right) \text {, } \\
\text { and human monoblast cell lineage, U937 } \\
\left.\text { (ATCC }{ }^{\circledR} \text { CRL-1593.2 }{ }^{\mathrm{TM}}\right)\end{array}$ & $\begin{array}{l}\text { PPYLSP, } \\
\text { IIGGAL and } \\
\text { FLPPVTSMG. }\end{array}$ & $\begin{array}{c}\downarrow \text { Expression of ICAM-1 and VCAM-1 induced by TNF- } \alpha \text {. } \\
\downarrow \text { Monocyte stems from EA.hy926 cells. The peptide with Met had } \\
\text { the best result. } \\
\downarrow \text { TNF- } \alpha \text {-induced superoxide formation in various degrees in } \\
\quad \text { EA.hy926 cells. } \\
\quad \downarrow \text { Expression of TNFR1 in EA.hy926 cells. } \\
\begin{array}{l}\text { Little effect on the expression of IkB } \alpha \text { and IkB } \beta \text { induced by } \\
\text { TNF- } \alpha\end{array} \\
\downarrow \text { Phosphorylation of p65: dummer involved in the NF-kB pathway. }\end{array}$ \\
\hline
\end{tabular}




\section{Metabolic Pathways of Inflammation in Obesity: Potential Therapeutic Targets for Hydrolyzed Proteins and Plant Peptides}

It is classic information that the white adipose tissue (WAT) is an endocrine organ, especially after discovering leptin. WAT has a primary function in energy metabolism through a metabolic network involving the central nervous system (CNS). In addition, it is responsible for secreting several adipokines and cytokines that have autocrine, paracrine and endocrine action-involving immune function and fundamental for the metabolism of sex steroids and glucocorticoids. Due to these numerous functions, excess WAT causes a series of metabolic disorders [46].

These disorders favor the increase in signaling for adipogenesis, causing both hypertrophy and hyperplasia of adipocytic cells, increased fatty acids, and circulating free inflammatory cytokines, as well as changes in the signaling of hormones that regulate the hunger-satiety axis. All these changes are complex and triggered by signaling pathways, genes and transcription factors $[12,47]$. Thus, it is essential to unveil potential molecular targets for the action of anti-inflammatory therapeutic agents.

In a study with adipose tissue cells extracted from rats and cells donated from patients who underwent bariatric surgery, Zhou et al. [48] described an association between low-grade chronic inflammation, caused by increased fat accumulation, and energy mitochondrial metabolism changes. The association was explained by increasing secretion and signaling of inflammatory cytokine IL- $1 \beta$, which interacts with the interleukin-1 receptor (IL-1R), recruiting the IL-1R-associated kinase 2 (IRAK) and myeloid differentiation primary response 88 (MyD88). With this activation, a cascade of protein interactions is triggered, affecting the morphology of the crests of the mitochondrial membrane, causing suppression of the electron carrier chain. This mechanism also impairs thermogenesis in brown adipose tissue (BAT). The outcome was the reduction in energy expenditure with the consequent increase in WAT $[9,48]$.

According to Zhou et al. [48], the discovery of this unconventional metabolic pathway, IL-1R-IRAK2, favors the search for therapeutic agents that have binding affinity with IRAK2 protein to minimize the inflammatory response induced by the increase in IL-1 $\beta$ affected by excess adipose tissue. Two pools of hydrolysis of plant protein, SBP [24], LPHs [29], FLV [39] and GPETAFLR [36,37], reduced the protein expression of IL-1 $\beta$, characterizing these molecules as potential anti-inflammatory agents acting in this signaling pathway.

This mechanism still unfolds, as reported by Yu et al. [49], in a study with macrophages derived from the bone marrow of rats with systemic inflammation induced by a high-fat diet and human low-density lipoprotein (LDL). The protein MyD88 interacted with TLRs, triggering an inflammatory response due to increased macrophage recruitment to the adipose tissue and polarization to the M1-like phenotype. As a result, insulin resistance increased. Among the studies included in the present review, SBP [24] acted to reduce the protein expression of TLR4, a beneficial action to attenuate the inflammatory response.

Furthermore, the increase in IL-1 $\beta$ also participates in the activation and positive reinforcement of the metabolic pathway of NF- $\mathrm{kB}$, classically known as the transcription factor related to the production of pro-inflammatory components. Mollaei et al. [50] presented in their review a cascade of activation of the NF- $\mathrm{KB}$ transcription pathway by LPS, in which, as soon as there is binding between LPS and the LPS binding protein (LBP), it triggers the following response: (1) phosphorylation of $\mathrm{I} \kappa \mathrm{B} \alpha,(2)$ degradation of I $\mathrm{B} \alpha,(3)$ activation of transcription factors that are taken to DNA and (4) signaling for the synthesis and release of chemokines-such as macrophage inflammatory protein-1 (MIP-1), MCP-1, also known as CCL2, and interferon (IFN)- $\gamma$ inducible protein 10 (IP-10) — and the release of enzymes-COX-2 and iNOS-and cytokines—such as IL-1 $\beta$, TNF- $\alpha$ and IL-6.

According to a study with adipocytes derived from ear mesenchymal stem cells (EMSC Ad) and dendritic bone marrow cells (BMDCs) of wild rats (C57Bl/6 J), knockout for TRL4 (Tlr4 ${ }^{-/-}$), fed ad libitum with feed containing $4.5 \%$ fat, this whole cascade was also triggered in the presence of saturated free fatty acids (AGLS) when binding to TLR4 and TLR2 [51]. 
Another study [52] also analyzed the action of free saturated fatty acid (FFA) on adipose tissue of wild rats $\left(\mathrm{C} 57 \mathrm{Bl} / 6 \mathrm{~J}\right.$ and $\left.T l r 4^{-/-}\right)$, and in obese rats knocked out for My88 (Myd88 $\left.{ }^{-/-}\right)$and for TIR domain-containing adapter protein-inducing interferon- $\beta$ (TRIF) (Trif $\left.{ }^{-/}\right)$, comparing animals with high-fat diet-induced obesity (HFD) (60\% of calories from lipids) and groups with diet containing $4.5 \%$ lipids. The TRL4 and the HFD conditions were fundamental for the increase in the recruitment of adipose tissue macrophages (ATMs) CD11c ${ }^{+}$. The presence of MyD88 and TRIF favor this recruitment, accentuating inflammation and culminating in macrophage polarization.

It is well documented that TRL4 is expressed in innate immune cells and other cell types, such as enterocytes and adipocytes, and both the presence of LPS and fatty acids can stimulate the inflammatory response via TRL4 [53,54]. Therefore, this pathway is essential in studying bioactives with anti-inflammatory potential. In the study by MartinezVillaluenga et al. [25], the pool of peptides of hydrolyzed soybean protein (SPH) reduced free fatty acids, evidencing a possible consistent therapeutic target in inflammation.

Moreover, in relation to the NF- $\kappa \mathrm{B}$ pathway, the hydrolyzed proteins of beans from the black $8025(\mathrm{~N})$, Pinto Durango (P) [26] and SBP varieties [24]; and peptides extracted from corn (zein) [45] and sunflower [42] were able to reduce NF- $\kappa$ B activity, consequently decreasing the expression of inflammatory cytokines, COX-2 and iNOS.

The signaling cascade of TNF- $\alpha$ is per si stimulated during obesity and hyperglycemia, causing an activation response of NF- $\mathrm{KB}$ that increases iNOS, which inhibits the substrate of the insulin receptor substrate 1 (IRS-1), and relates to the increase in OE, hindering the functioning of mitochondria and causing a reduction in $\beta$-oxidation [55-58]. This signaling pathway is of great importance in studies of obesity and inflammation because the peptides of zein [45] reduced the expression of the TNF- $\alpha$ receptor. In addition, the octapeptide of lupine [36], FLV [39], the hydrolysis pool of SBP [24] and LPHs [29] reduced the cytokine expression, aiding in reducing the entire cascade related to the TNF- $\alpha$ signal.

Another signaling pathway involved in inflammation is JAK/STAT (Janus kinase and transducer signal and activator of transcription), which regulates the synthesis of inflammatory cytokines, hormones and growth factors by rapid transduction of intracellular signal [59]. The signaling cascade occurs through the communication between cytokines and class I and II receptors in the cell membrane, causing activation of JAKs [60], which phosphorylate and allow the fitting with STAT proteins, which are also phosphorylated. Thus, STAT multidimers can promote epigenetic changes by regulating gene transcription in the nucleus $[61,62]$. Considering the JAK/STAT pathway, most hydrolyzed proteins and peptides acted by minimizing this activation cascade. These potential anti-inflammatory agents decrease the protein expression of several cytokines that positively feed the pathway.

JAK/STAT signaling is determinant in cellular communication because several types of JAK and STAT guarantee specificity [61]. The leptin/JAK2/STAT3 pathway is positively refueled by IL-6, and this activation profile is fundamental for the development of insulin resistance and inflammation-related glucose intolerance. STAT3 is a facilitating agent of adipogenesis through the peroxisome proliferator-activated receptor (PPAR- $\gamma$ ) [54,63].

In obesity, there is also an increase in the synthesis and release of IL-6, which acts on STAT3, favoring the activation of the suppressor of cytokine signaling 3 (SOCS3) $[63,64]$. In the study by Shi et al. [64] in 3T3-L1 adipose tissue cells, SOCS3 inhibited IRS-1, thus inhibiting the PIK3-AKT signaling pathway, causing insulin resistance (IR).

Regarding IR, it is still discussed that the recruitment or replication of M1 in the pancreas, in the condition of excess adipose tissue, promotes hyperplasia and dysfunction of $\beta$-cells, therefore impairing insulin secretion. Thus, the metabolic pathways related to glucose metabolism are potential therapeutic targets [65].

Furthermore, among the vegetable peptides, the peptide Leg (Leg_1_37 and Leg_1_36) [40] was able to increase the activity of the phosphatidylinositol 3-kinase (PI3K) and AKT pathways, favoring GLUT-4 translocation and assisting in the reduction of IR, minimizing IR and improving inflammation. 
STAT3 also regulates hematopoiesis and signaling for immune cells, as is the case with T helper 17 (Th17) lymphocytes. The differentiation process of Th17 occurs in response to STAT3 to low concentration signaling of IL-21, IL-6 and IL-23, in addition to beta growth transformation factor (TGF- $\beta$ ) and IL-1, by means other than STAT3 [66]. Th17 cells secrete IL-17, which contributes to an increased macrophage-mediated pro-inflammatory response inducing secretion of IL-1 $\beta$, IL-6 and TNF- $\alpha[6,67]$. Therefore, due to JAK/STAT dysregulation not only in obesity but also in T2DM and MS, it is a potential therapeutic target for such metabolic disorders [68].

Figure 1 shows updates on the metabolic pathways of obesity inflammation and the potential therapeutic targets of hydrolyzed proteins and purified peptides in a hypothetical eukaryotic cell. Studies have their limitations, either by the experimental model used or by the study design, which do not cancel the possibility of effects by other mechanisms. Among the 13 included studies using peptide pools, one study addressed the improvement in the profile of enzymes related to hepatic detoxification [30], seven analyzed the reduction in oxidative stress and increased antioxidant activity [25,26,29,30,33,36,37], five studies found reduction in NF-KB $[24,26,39,42,45]$, two verified glucose uptake pathways $[39,40]$ and all 13 analyzed inflammatory cytokines, mainly TNF- $\alpha$ and IL- $1 \beta$, and improvements in immunomodulation [24-27,29,30,33,36,37,39,40,42,45].

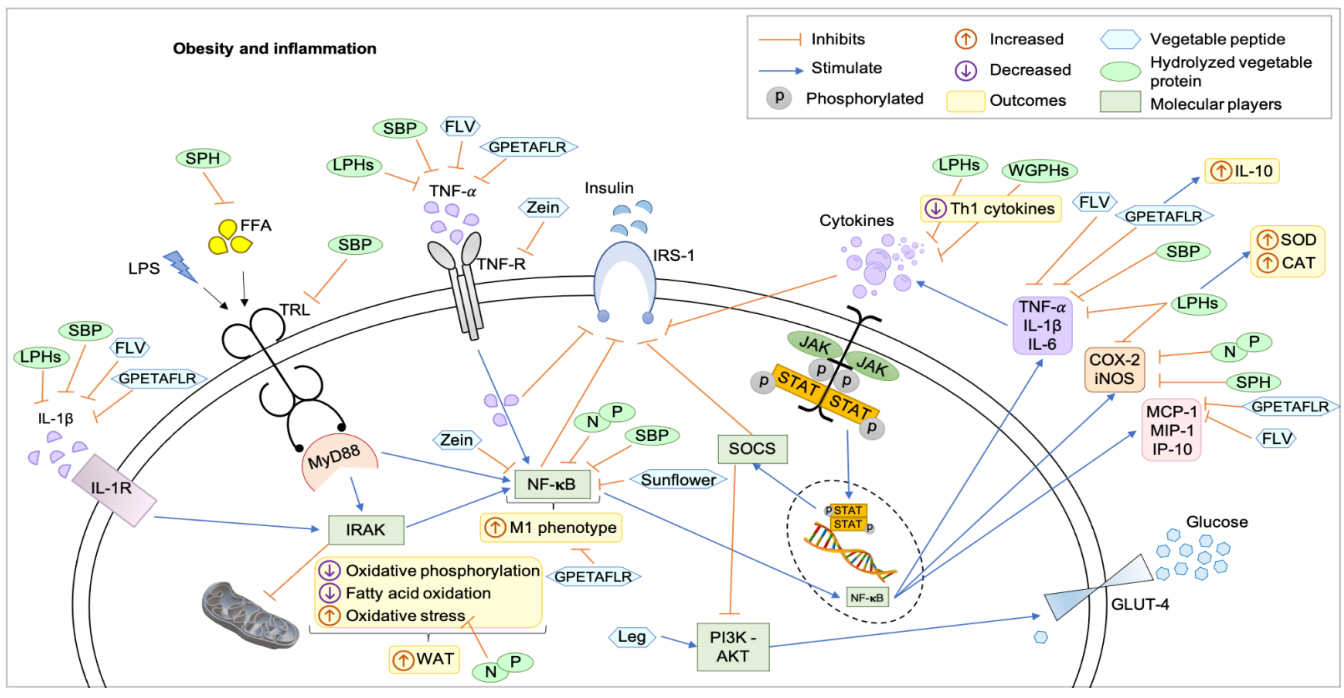

Figure 1. Mechanisms of action of hydrolyzed proteins and plant peptides on obesity and inflammation in a hypothetical eukaryotic cell. All hydrolyzed proteins and peptides acted to reduce inflammation through metabolic pathways that communicate and are responsible for the positive feedback cascade for the accumulation of more adipose tissue and subclinical inflammation, as well as some compounds acted by feeding detoxification and detoxification pathways. reduction of oxidative stress. CAT: catalase, COX2: cyclooxygenase-2, FFA: free fatty acid, FLV: soy peptide Phe-Leu-Val, GLUT4: glucose transporter type 4, GPETAFLR: peptide from Lupinus angustifolius L., IL-10: interleukins-10, IL-6: interleukins6, IL1- $\beta$ : interleukins-1 $\beta$, IL1-R: interleukins-1-receptor, iNOS: inducible nitric oxide synthase, IP-10: interferon-inducible protein 10, IRAK: IL-1R-associated kinase 2, IRS-1: insulin receptor substrate 1, JAK-STAT: Janus kinase-signal transducer and activator of transcription, Leg: Leginsulin, LPHs: lupine protein hydrolysates, LPS: lipopolysaccharides, M1: M1-like macrophage, MCP-1: monocyte chemoattractant protein-1, MIP-1: macrophage inflammatory protein-1, MyD88: myeloid differentiation primary response 88, N and P: protein hydrolysates of the common bean (Phaseolus vulgaris L.) varieties Negro 8025 and Pinto Durango, NFkB: factor nuclear kappa B, PI3K-AKT: phosphatidylinositol 3kinase/protein kinase B, SBP: soybean protein-derived peptides, SOCS: suppressor of cytokine signaling, SOD: superoxide dismutase, SPH: soy protein peptic hydrolysate, sunflower: peptides from sunflower protein hydrolysate, Th1: T helper 1, TNF- $\alpha$ : tumor necrosis factor- $\alpha$, TNF-R: tumor necrosis factorreceptor, TRL: toll-like receptor, WAT: white adipose tissue, WGPHs: wheat gluten protein hydrolysates, zein: peptides for zein hydrolysate. 
Therefore, the mechanisms of action were the reduction in inflammatory cytokines and enzymes involved with the inflammatory process; inhibition of NF- $\mathrm{kB}$; reduction in $\mathrm{OE}$; stimulation of the PI3K-AKT pathway and enzymes related to detoxification.

All the studies discussed in this review were conducted in cell cultures except for one, which was an in vitro enzymatic assay. This shows the need to deepen the studies through research in animals and in clinical trials. However, a determining limitation, which contributes to the difficulty in making original articles in an animal model with bioactive peptides, is the high financial cost [69]. In addition, there is a long methodological process to purify a plant [70], hydrolyze in sufficient quantity to test in animals and synthesize and identify peptides so that the mechanism of action involved is established.

Bioinformatics can help predict molecular targets that have a potential affinity for compounds or molecules of interest and identify new biomarkers for prognosis and diagnosis, identifying and analyzing differentially expressed genes (DEGs) in various diseases [71,72]. Moreover, this area can also contribute to the search for alternative drugs for new diseases, providing an extremely useful tool to accelerate urgent studies for the selection of these drugs, understanding and possibly helping in the treatment of new diseases, whether chronic, such as obesity, or acute and emerging, as in the case of coronavirus disease-19 (COVID-19)—since bioinformatics was and still is an essential method to perform sequencing data analysis, pandemic tracking and analysis of pandemic containment measures [73-75].

\section{Conclusions}

The present review showed that hydrolyzed proteins and peptides of plant sources are promising molecules both as anti-inflammatory agents and with immunomodulatory function, presenting mechanisms of action in several metabolic pathways that correlate. According to the evaluated studies, it is possible to infer that this anti-inflammatory activity is directly related to the polarization of macrophages to the M2 phenotype. However, there is a need for more understanding of these molecules of natural origin using other types of studies, extrapolating the limitations of research that use cell and ex vivo culture. Thus, the development of bioinformatics tools for such analysis is supported to predict molecular targets that are determinant in overweight and obesity and other emerging diseases, adding to different research strategies that safely promote potential new bioactive molecules.

Author Contributions: Literature review: A.F.d.M. and J.L.C.d.Q.; original draft preparation: A.F.d.M. and A.H.d.A.M.; writing, critical review and editing: A.F.d.M., J.L.C.d.Q., B.L.L.M. and A.H.d.A.M.; supervision: A.H.d.A.M. All authors have read and agreed to the published version of the manuscript.

Funding: This work was supported for scholarship and payment of fees by the Coordenação de Aperfeiçoamento de Pessoal de Nível Superior (Finance Code 001-CAPES), the Conselho Nacional de Desenvolvimento Cientítico e Tecnológico (Award Number: 426116/2018-6-CNPq) research promotion agencies.

Institutional Review Board Statement: Not applicable.

Informed Consent Statement: Not applicable.

Data Availability Statement: Not applicable.

Conflicts of Interest: The authors declare no conflict of interest.

\section{References}

1. Vandevijvere, S.; Kraak, V. Future directions to prevent obesity within the context of the Global Syndemic. Obes. Rev. 2019, 20, 3-5. [CrossRef]

2. World Obesity Federation Global Obesity Observatory the Economic Impact of Overweight \& Obesity. Available online: https:/ / data.worldobesity.org/costs/\#rlslider_2 (accessed on 15 January 2021).

3. World Health Organization Obesity and Overweight: Key Facts. Available online: https://www.who.int/news-room/factsheets/detail/obesity-and-overweight (accessed on 14 January 2021).

4. WHO. Obesity. Available online: https://www.who.int/health-topics/obesity\#tab=tab_1 (accessed on 14 January 2021). 
5. Guillet, C.; Masgrau, A.; Walrand, S.; Boirie, Y. Impaired protein metabolism: Interlinks between obesity, insulin resistance and inflammation. Obes. Rev. 2012, 13, 51-57. [CrossRef]

6. Pereira, S.S.; Alvarez-Leite, J.I. Low-Grade Inflammation, Obesity, and Diabetes. Curr. Obes. Rep. 2014, 3, 422-431. [CrossRef] [PubMed]

7. Wang, L.; Sun, P.; Wu, Y.; Wang, L. Metabolic tissue-resident CD8 ${ }^{+}$T cells: A key player in obesity-related diseases. Obes. Rev. 2020, 22, e13133. [CrossRef]

8. Taylor, E.B. The complex role of adipokines in obesity, inflammation, and autoimmunity. Clin. Sci. 2021, 135, 731-752. [CrossRef] [PubMed]

9. Tavernarakis, N. Inflammation brakes mitochondrial metabolism in obesity. Nat. Immunol. 2020, 21, 1143-1145. [CrossRef]

10. De Heredia, F.P.; Gómez-Martínez, S.; Marcos, A. Chronic and degenerative diseases: Obesity, inflammation and the immune system. Proc. Nutr. Soc. 2012, 71, 332-338. [CrossRef] [PubMed]

11. Karczewski, J.; Śledzińska, E.; Baturo, A.; Jończyk, I.; Maleszko, A.; Samborski, P.; Begier-Krasińska, B.; Dobrowolska, A. Obesity and inflammation. Eur. Cytokine Netw. 2018, 29, 83-94. [CrossRef] [PubMed]

12. Jack, B.U.; Malherbe, C.J.; Mamushi, M.; Muller, C.J.F.; Joubert, E.; Louw, J.; Pheiffer, C. Adipose tissue as a possible therapeutic target for polyphenols: A case for Cyclopia extracts as anti-obesity nutraceuticals. Biomed. Pharmacother. 2019, 120, 109439. [CrossRef]

13. Nascimento, S.S.C. Mecanismos de Ação de Agentes Anti-Inflamatórios no Tecido Adiposo. Masters Thesis, Universidade Federal do Rio Grande do Norte, Natal, Brazil, 30 March 2021.

14. Nasri, H.; Baradaran, A.; Shirzad, H.; Kopaei, M.R. New concepts in nutraceuticals as alternative for pharmaceuticals. Int. J. Prev. Med. 2014, 5, 1487-1499.

15. Nijhawan, P.; Behl, T. Nutraceuticals in the management of obesity. Obes. Med. 2020, 17, 100168. [CrossRef]

16. Hardy, G. Nutraceuticals and functional foods: Introduction and meaning. Nutrition 2000, 16, 688-689. [CrossRef]

17. Chakrabarti, S.; Guha, S.; Majumder, K. Food-derived bioactive peptides in human health: Challenges and opportunities. Nutrients 2018, 10, 1738. [CrossRef] [PubMed]

18. Reyes-Díaz, A.; Del-Toro-Sánchez, C.L.; Rodríguez-Figueroa, J.C.; Valdéz-Hurtado, S.; Wong-Corral, F.J.; Borboa-Flores, J.; González-Osuna, M.F.; Perez-Perez, L.M.; González-Vega, R.I. Legume Proteins as a Promising Source of Anti-Inflammatory Peptides. Curr. Protein Pept. Sci. 2019, 20, 1204-1217. [CrossRef]

19. Chalamaiah, M.; Yu, W.; Wu, J. Immunomodulatory and anticancer protein hydrolysates (peptides) from food proteins: A review. Food Chem. 2018, 245, 205-222. [CrossRef]

20. Jakubczyk, A.; Karas, M.; Rybczynska-Tkaczyk, K.; Zielinska, E.; Zielinski, D. Current trends of bioactive peptides-New sources and therapeutic effect. Foods 2020, 9, 846. [CrossRef]

21. Zhu, W.; Ren, L.; Zhang, L.; Qiao, Q.; Farooq, M.Z.; Xu, Q. The Potential of Food Protein-Derived Bioactive Peptides against Chronic Intestinal Inflammation. Mediat. Inflamm. 2020, 2020, 6817156. [CrossRef]

22. Matemu, A.; Nakamura, S.; Katayama, S. Health benefits of antioxidative peptides derived from legume proteins with a high amino acid score. Antioxidants 2021, 10, 316. [CrossRef]

23. Modgil, R.; Tanwar, B.; Goyal, A.; Kumar, V. Soybean (Glycine max). In Oilseeds: Health Attributes and Food Applications; Tanwar, B., Goyal, A., Eds.; Springer: Singapore, 2020; ISBN 978-981-15-4193-3.

24. Yi, G.; Li, H.; Liu, M.; Ying, Z.; Zhang, J.; Liu, X. Soybean protein-derived peptides inhibit inflammation in LPS-induced RAW264.7 macrophages via the suppression of TLR4-mediated MAPK-JNK and NF-kappa B activation. J. Food Biochem. 2020, 44, e13289. [CrossRef] [PubMed]

25. Martinez-Villaluenga, C.; Dia, V.P.; Berhow, M.; Bringe, N.A.; de Mejia, E.G. Protein hydrolysates from $\beta$-Conglycinin enriched soybean genotypes inhibit lipid accumulation and inflammation in vitro. Mol. Nutr. Food Res. 2009, 53, 1007-1018. [CrossRef]

26. Oseguera-Toledo, M.E.; De Mejia, E.G.; Dia, V.P.; Amaya-Llano, S.L. Common bean (Phaseolus vulgaris L.) hydrolysates inhibit inflammation in LPS-induced macrophages through suppression of NF-kB pathways. Food Chem. 2011, 127, 1175-1185. [CrossRef]

27. Millán-Linares, M.D.C.; Yust, M.D.M.; Alcaide-Hidalgo, J.M.; Millán, F.; Pedroche, J. Lupine protein hydrolysates inhibit enzymes involved in the inflammatory pathway. Food Chem. 2014, 151, 141-147. [CrossRef]

28. Nelson, D.L.; Cox, M.M. Lehninger Principles of Biochemistry, 6th ed.; W.H.Freeman and Company, Ed.; Worth Publishers: New York, NY, USA, 2014; ISBN 9781429234146.

29. Millán-Linares, M.d.C.; Bermúdez, B.; Yust, M.d.M.; Millán, F.; Pedroche, J. Anti-inflammatory activity of lupine (Lupinus angustifolius L.) protein hydrolysates in THP-1-derived macrophages. J. Funct. Foods 2014, 8, 224-233. [CrossRef]

30. Cruz-Chamorro, I.; Álvarez-Sánchez, N.; Millán-Linares, M.d.C.; Yust, M.d.M.; Pedroche, J.; Millán, F.; Lardone, P.J.; Carrera-Sánchez, C.; Guerrero, J.M.; Carrillo-Vico, A. Lupine protein hydrolysates decrease the inflammatory response and improve the oxidative status in human peripheral lymphocytes. Food Res. Int. 2019, 126, 108585. [CrossRef] [PubMed]

31. Saha, S.K.; Lee, S.B.; Won, J.; Choi, H.Y.; Kim, K.; Yang, G.M.; Dayem, A.A.; Cho, S.G. Correlation between oxidative stress, nutrition, and cancer initiation. Int. J. Mol. Sci. 2017, 18, 1544. [CrossRef] [PubMed]

32. Tobore, T.O. Towards a comprehensive theory of obesity and a healthy diet: The causal role of oxidative stress in food addiction and obesity. Behav. Brain Res. 2020, 384, 112560. [CrossRef] 
33. Cruz-Chamorro, I.; Álvarez-Sánchez, N.; Santos-Sánchez, G.; Pedroche, J.; Fernández-Pachón, M.S.; Millán, F.; Millán-Linares, M.C.; Lardone, P.J.; Bejarano, I.; Guerrero, J.M.; et al. Immunomodulatory and antioxidant properties of wheat gluten protein hydrolysates in human peripheral blood mononuclear cells. Nutrients 2020, 12, 1673. [CrossRef]

34. Malalgoda, M.; Manthey, F.; Simsek, S. Reducing the celiac disease antigenicity of wheat. Cereal Chem. 2018, 95, 49-58. [CrossRef]

35. Costa, I.S.; Medeiros, A.F.; Piuvezam, G.; Medeiros, G.C.; Maciel, B.L.; Morais, A.H.A.M. Insulin-Like Proteins in Plant Sources: A Systematic Review. Diabetes Metab. Syndr. Obes. Targets Ther. 2020, 13, 3421-3431. [CrossRef] [PubMed]

36. Millán-Linares, M.d.C.; Millán, F.; Pedroche, J.; del Yust, M. GPETAFLR: A new anti-inflammatory peptide from Lupinus angustifolius L. protein hydrolysate. J. Funct. Foods 2015, 18, 358-367. [CrossRef]

37. La Paz, S.M.-D.; Lemus-Conejo, A.; Toscano, R.; Pedroche, J.; Millan, F.; Millan-Linares, M.C. GPETAFLR, an octapeptide isolated from: Lupinus angustifolius L. Protein hydrolysate, promotes the skewing to the M2 phenotype in human primary monocytes. Food Funct. 2019, 10, 3303-3311. [CrossRef]

38. Friedrich, K.; Sommer, M.; Strobel, S.; Thrum, S.; Blüher, M.; Wagner, U.; Rossol, M. Perturbation of the monocyte compartment in human obesity. Front. Immunol. 2019, 10, 1874. [CrossRef] [PubMed]

39. Kwak, S.J.; Kim, C.S.; Choi, M.S.; Park, T.; Sung, M.K.; Yun, J.W.; Yoo, H.; Mine, Y.; Yu, R. The Soy Peptide Phe-Leu-Val Reduces TNF $\alpha$-Induced Inflammatory Response and Insulin Resistance in Adipocytes. J. Med. Food 2016, 19, 678-685. [CrossRef]

40. Hashidume, T.; Sakano, T.; Mochizuki, A.; Ito, K.; Ito, S.; Kawarasaki, Y.; Miyoshi, N. Identification of soybean peptide leginsulin variants in different cultivars and their insulin-like activities. Sci. Rep. 2018, 8, 16847. [CrossRef] [PubMed]

41. Komatsu, S.; Hirano, H. Plant basic $7 \mathrm{~S}$ globulin-like proteins have insulin and insulin-like growth factor binding activity. FEBS Lett. 1991, 294, 210-212. [CrossRef]

42. Velliquette, R.A.; Fast, D.J.; Maly, E.R.; Alashi, A.M.; Aluko, R.E. Enzymatically derived sunflower protein hydrolysate and peptides inhibit NFKB and promote monocyte differentiation to a dendritic cell phenotype. Food Chem. 2020, $319,126563$. [CrossRef] [PubMed]

43. Gualano, M.; Berti, F.; Stramentinoli, G. Anti-inflammatory activity of S-adenosyl-L-methionine in animal models: Possible interference with the eicosanoid system. Int. J. Tissue React. 1985, 7, 41-46.

44. Ouyang, Y.; Wu, Q.; Li, J.; Sun, S.; Sun, S. S-adenosylmethionine: A metabolite critical to the regulation of autophagy. Cell Prolif. 2020, 53, e12891. [CrossRef]

45. Liang, Q.; Chalamaiah, M.; Liao, W.; Ren, X.; Ma, H.; Wu, J. Zein hydrolysate and its peptides exert anti-inflammatory activity on endothelial cells by preventing TNF- $\alpha$-induced NF- $\mathrm{kB}$ activation. J. Funct. Foods 2020, 64, 103598. [CrossRef]

46. Kershaw, E.E.; Flier, J.S. Adipose Tissue as an Endocrine Organ. J. Clin. Endocrinol. Metab. 2004, 89, 2548-2556. [CrossRef]

47. Jakab, J.; Miškić, B.; Mikšić, Š.; Juranić, B.; Ćosić, V.; Schwarz, D.; Včev, A. Adipogenesis as a potential anti-obesity target: A review of pharmacological treatment and natural products. Diabetes Metab. Syndr. Obes. Targets Ther. 2021, 14, 67-83. [CrossRef]

48. Zhou, H.; Wang, H.; Yu, M.; Schugar, R.C.; Qian, W.; Tang, F.; Liu, W.; Yang, H.; McDowell, R.E.; Zhao, J.; et al. IL-1 induces mitochondrial translocation of IRAK2 to suppress oxidative metabolism in adipocytes. Nat. Immunol. 2020, 21, 1219-1231. [CrossRef]

49. Yu, M.; Zhou, H.; Zhao, J.; Xiao, N.; Roychowdhury, S.; Schmitt, D.; Hu, B.; Harding, C.V.; Hise, A.G.; Hazen, S.L.; et al. MyD88dependent interplay between myeloid and endothelial cells in the initiation and progression of obesity-associated inflammatory diseases. J. Exp. Med. 2014, 211, 887-907. [CrossRef]

50. Mollaei, M.; Abbasi, A.; Hassan, Z.M.; Pakravan, N. The intrinsic and extrinsic elements regulating inflammation. Life Sci. 2020, 260, 118258. [CrossRef]

51. McKernan, K.; Varghese, M.; Patel, R.; Singer, K. Role of TLR4 in the induction of inflammatory changes in adipocytes and macrophages. Adipocyte 2020, 9, 212-222. [CrossRef] [PubMed]

52. Griffin, C.; Eter, L.; Lanzetta, N.; Abrishami, S.; Varghese, M.; McKernan, K.; Muir, L.; Lane, J.; Lumeng, C.N.; Singer, K. TLR4, TRIF, and MyD88 are essential for myelopoiesis and CD11c adipose tissue macrophage production in obese mice. J. Biol. Chem. 2018, 293, 8775-8786. [CrossRef]

53. Rogero, M.M.; Calder, P.C. Obesity, inflammation, toll-like receptor 4 and fatty acids. Nutrients 2018, 10, 432. [CrossRef]

54. Seong, J.; Kang, J.Y.; Sun, J.S.; Kim, K.W. Hypothalamic inflammation and obesity: A mechanistic review. Arch. Pharm. Res. 2019, 42, 383-392. [CrossRef] [PubMed]

55. Kanehisa, M.; Furumichi, M.; Sato, Y.; Ishiguro-Watanabe, M.; Tanabe, M. KEGG: Integrating viruses and cellular organisms. Nucleic Acids Res. 2021, 49, D545-D551. [CrossRef]

56. Kanehisa, M. Toward understanding the origin and evolution of cellular organisms. Protein Sci. 2019, 28, 1947-1951. [CrossRef] [PubMed]

57. Kanehisa, M.; Goto, S. KEGG: Kyoto Encyclopedia of Genes and Genomes. Nucleic Acids Res. 2000, 28, 27-30. [CrossRef]

58. Kanehisa Laboratories. KEGG PATHWAY: Insulin Resistance. Available online: https://www.kegg.jp/kegg-bin/highlight_ pathway?scale=1.0\&map=map04931\&keyword=stat3 (accessed on 4 February 2021).

59. Gurzov, E.N.; Stanley, W.J.; Pappas, E.G.; Thomas, H.E.; Gough, D.J. The JAK/STAT pathway in obesity and diabetes. FEBS J. 2016, 283, 3002-3015. [CrossRef]

60. Morris, R.; Kershaw, N.J.; Babon, J.J. The molecular details of cytokine signaling via the JAK/STAT pathway. Protein Sci. 2018, 27, 1984-2009. [CrossRef]

61. Muller, R. JAK inhibitors in 2019, synthetic review in 10 points. Eur. J. Intern. Med. 2019, 66, 9-17. [CrossRef] [PubMed] 
62. Kotyla, P.J.; Islam, M.A.; Engelmann, M. Clinical aspects ofJanuaryus Kinase (JAK) inhibitors in the cardiovascular system in patients with rheumatoid arthritis. Int. J. Mol. Sci. 2020, 21, 7390. [CrossRef]

63. Bharadwaj, U.; Kasembeli, M.M.; Robinson, P.; Tweardy, D.J. TargetingJanuaryus Kinases and Signal Transducer and Activator of Transcription 3 to Treat Inflammation, Fibrosis, and Cancer: Rationale, Progress, and Caution. Pharmacol. Rev. 2020, 72, 486-526. [CrossRef]

64. Shi, H.; Tzameli, I.; Bjørbæk, C.; Flier, J.S. Suppressor of cytokine signaling 3 is a physiological regulator of adipocyte insulin signaling. J. Biol. Chem. 2004, 279, 34733-34740. [CrossRef]

65. Ying, W.; Fu, W.; Lee, Y.S.; Olefsky, J.M. The role of macrophages in obesity-associated islet inflammation and $\beta$-cell abnormalities. Nat. Rev. Endocrinol. 2020, 16, 81-90. [CrossRef] [PubMed]

66. Kanehisa Laboratories KEGG. PATHWAY: Th17 Cell Differentiation-Homo Sapiens (Human). Available online: https://www. genome.jp/kegg-bin/show_pathway?hsa04659 (accessed on 4 February 2021).

67. Winer, S.; Chan, Y.; Paltser, G.; Truong, D.; Tsui, H.; Bahrami, J.; Dorfman, R.; Wang, Y.; Zielenski, J.; Mastronardi, F.; et al. Normalization of obesity-associated insulin resistance through immunotherapy. Nat. Med. 2009, 15, 921-929. [CrossRef] [PubMed]

68. Dodington, D.W.; Desai, H.R.; Woo, M. JAK/STAT-Emerging Players in Metabolism. Trends Endocrinol. Metab. 2018, 29, 55-65. [CrossRef]

69. Van Norman, G.A. Limitations of Animal Studies for Predicting Toxicity in Clinical Trials: Is it Time to Rethink Our Current Approach? JACC Basic Transl. Sci. 2019, 4, 845-854. [CrossRef] [PubMed]

70. Boxi, A.; Parikh, I.; Sivaprasad, R.; Shreekar, S.K. Current Trends in Protein Purification: A Review. Int. J. Sci. Res. Sci. Technol. 2020, 7, 279-310. [CrossRef]

71. Prashanth, G.; Vastrad, B.; Tengli, A.; Vastrad, C.; Kotturshetti, I. Investigation of candidate genes and mechanisms underlying obesity associated type 2 diabetes mellitus using bioinformatics analysis and screening of small drug molecules. BMC Endocr. Disord. 2021, 21, 80. [CrossRef]

72. Dong, Z.; Lei, X.; Kujawa, S.A.; Bolu, N.; Zhao, H.; Wang, C. Identification of core gene in obese type 2 diabetes patients using bioinformatics analysis. Adipocyte 2021, 10, 310-321. [CrossRef]

73. Hufsky, F.; Lamkiewicz, K.; Almeida, A.; Aouacheria, A.; Arighi, C.; Bateman, A.; Baumbach, J.; Beerenwinkel, N.; Brandt, C.; Cacciabue, M.; et al. Computational strategies to combat COVID-19: Useful tools to accelerate SARS-CoV-2 and coronavirus research. Brief. Bioinform. 2021, 22, 642-663. [CrossRef] [PubMed]

74. Sookaromdee, P.; Wiwanitkit, V. Bioinformatics Analysis for Screening of Therapeutic Drugs in COVID-19. Arch. Med. Res. 2021, 52, 572. [CrossRef]

75. Morais, A.H.A.; Medeiros, A.F.; Medeiros, I.; Lima, V.C.O.; Luz, A.B.S.; Maciel, B.L.L.; Passos, T.S. Tamarind (Tamarindus indica L.) Seed a Candidate Protein Source with Potential for Combating SARS-CoV-2 Infection in Obesity. Drug Target Insights 2021, 15, 5-12. [CrossRef] 